\title{
ANALISIS KELONGSORAN TEBING DI JALAN AHMAD YANI KABUPATEN MURUNG RAYA PROVINSI KALIMANTAN TENGAH
}

\author{
Novry Saut Parulian Silaban \\ Jurusan/Program Studi Teknik Sipil, Fakultas Teknik, Universitas Palangka Raya \\ Jln. Hendrik Timang, Palangka Raya, e-mail: novrysilaban@gmail.com \\ M. Ikhwan Yani \\ Jurusan/Program Studi Teknik Sipil, Fakultas Teknik, Universitas Palangka Raya \\ Jln. Hendrik Timang, Palangka Raya, e-mail: borneo.geotech@gmail.com \\ Okrobianus Hendri \\ Jurusan/Program Studi Teknik Sipil, Fakultas Teknik, Universitas Palangka Raya \\ Jln. Hendrik Timang, Palangka Raya, e-mail: okrobianus@ gmail.com
}

\begin{abstract}
The Landslide is a common geological symptom, and it will occur to seek balance of nature. The main factor causes the avalanche is a geological factor, climate, vegetation, and land use. The research area located in Murung Raya district, precisely on Ahmad Yani street. Murung Raya area is one of the potential disaster of landslides. Murung Raya area is a highly to volatile zone area so that it becomes one of the causes of avalanche. The General avalanche occurs in a heavy rain. When the rainy season arrives, the amount of infiltration water impacts on the land's saturation, was easily destroyed and the ground aggression became extremely weak so the shear resistance of the soil decreases.In this research to determine the security factor in the avalance area using manual calculations with the Bishop Method. Parameters used to determine security factors on the slope is a sliding angle $(\varphi)$ and cohesion $(C)$. In the first layer the value $\varphi=10^{\circ}$ and the value of $C=130$ $\mathrm{kN} / \mathrm{m}^{3}$, in the second layer the value $\varphi=16^{\circ}$ and $\mathrm{C}$ value $=90 \mathrm{kN} / \mathrm{m}^{3}$. From the calculations on the security factor on the avalanche of the $\mathrm{FK}=0,91$. With the security factor that is found including critical or has been avalanche and need to be done with a good countermeasures boosting walls of the previous lansdcape.
\end{abstract}

Keywords: safety factors, cohesion, landslide, soil classification systems, sliding corners

\begin{abstract}
Abstrak: Longsor merupakan gejala geologi yang umum terjadi dan akan terjadi untuk mencari keseimbangan alam. Faktor utama yang menyebabkan longsor adalah faktor geologi, iklim, vegetasi dan penggunaan lahan. Daerah kajian penilitian ini berlokasi di Kabupaten Murung Raya tepatnya di jalan Ahmad Yani. Kabupaten Murung Raya merupakan salah satu daerah yang memiliki potensi bencana tanah longsor. Kabupaten Murung Raya merupakan daerah dengan topografi berbukit hingga bergunung sehingga hal tersebut menjadi salah satu penyebab terjadinya bahaya longsor. Umumnya longsor terjadi pada saat hujan lebat. Ketika musim hujan tiba terjadilah peningkatan jumlah air infiltrasi yang berdampak pada tanah jenuh air, maka pori tanah mudah hancur dan agregasi tanah menjadi sangat lemah sehingga ketahanan geser tanah menurun. Dalam penelitian ini untuk menentukan faktor keamanan pada daerah longsoran menggunakan perhitungan manual dengan Metode Bishop. Parameter yang digunakan untuk menentukan faktor keamanan pada lereng yaitu sudut geser dalam $(\varphi)$ dan kohesi $(C)$. Pada lapisan pertama nilai $\varphi=10^{\circ}$ dan nilai $\mathrm{C}=130$ $\mathrm{kN} / \mathrm{m}^{3}$, pada lapisan kedua nilai $\varphi=16^{\circ}$ dan nilai $\mathrm{C}=90 \mathrm{kN} / \mathrm{m}^{3}$. Dari hasil analisis perhitungan di dapat faktor keamanan pada daerah longsoran $\mathrm{FK}=0,91$. Dengan faktor keamanan yang di dapat termasuk kritis atau sudah terjadi longsoran dan perlu dilakukan penanggulangan yang baik dengan meningkatkan dinding penahan tanah yang ada sebelumnya.
\end{abstract}

Kata kunci: : faktor keamanan, kohesi, longsor, sistem klasifikasi tanah, sudut geser dalam 


\section{PENDAHULUAN}

\section{Latar Belakang}

Longsor merupakan gejala geologi yang umum terjadi dan akan terjadi untuk mencari keseimbangan alam. Faktor utama yang menyebabkan longsor adalah faktor geologi, iklim, vegetasi dan penggunaan lahan. Daerah kajian penilitian adalah di kabupaten Murung Raya yang beribukota Kabupaten Puruk Cahu tepatnya di jalan Ahmad Yani. Kabupaten Murung Raya merupakan salah satu daerah yang memiliki potensi bencana tanah longsor. Kabupaten Murung Raya merupakan daerah dengan topografi berbukit hingga bergunung sehingga hal tersebut menjadi salah satu penyebab terjadinya bahaya longsor.

Lereng memiliki permukaan yang terjal dan miring dan rawan terkena longsor. Selain permukaan yang miring, gaya gravitasi juga memengaruhi massa tanah bergerak ke bawah untuk mencari kesetimbangan yang baru. Longsor juga terjadi akibat adanya perubahan massa tanah yang diakibatkan hujan dan saat air meresap ke dalam tanah disitulah tanah mengalami penambahan massa tanah yang memaksa tanah mulai bergerak ke bawah.

Pada penelitian ini menggunakan metode analisis balik untuk menganalisis kasus kelongsoran yang berada di jalan Ahmad Yani. Penggunaan metode analisis balik untuk mengetahui berapa besar nilai $\phi$ dan $C$ dari tanah timbunan yang menyebabkan lereng pada kondisi kritis . Kondisi ini dapat disebut juga sebagai kondisi ambang batas. Bila nilai $\phi$ dan $C$ lebih dari nilai ambang batas, maka pada saat nilai $\phi$ dan $C$ tersebut mengakibatkan lereng mengalami longsor. Dari penjelasan dan studi kasus yang akan dikaji pada penelitian ini, adalah menentukan nilai $\phi$ dan $\mathrm{C}$ pada kondisi kritis . Dengan mencocokkan model longsoran dari hasil analisis dengan kondisi lapangan.

Menurut data BPS Kabupaten Murung Raya keadaan wilayahnya Kabupaten Murung Raya tanahnya terdiri dari berbukit-bukit dengan ketinggian dari permukaan laut antara 123-700 m. Potensi hidrologi Kabupaten Murung Raya cukup besar, terutama adanya aliran beberapa sungai antara lain Sungai Barito, Sungai Babuat, Sungai Busang, Sungai Laung, Sungai Joloi, dan beberapa sungai kecil lainnya.

\section{Rumusan Masalah}

1. Berapa besarnya nilai $\phi$ dan $\mathrm{C}$ dari hasil analisis yang menunjukkan FK kritis?
2. Berapakah nilai $\phi$ dan $\mathrm{C}$ ambang batas yg sesuai dengan kondisi lapangan?

\section{Batasan Masalah}

1. Analisis sifat fisik dan mekanik tanah hanya pada lokasi longsor di jalan Ahmad Yani.

2. Analisis sifat fisik dan mekanik tanah hanya pada lokasi longsor di jalan Ahmad Yani.

3. Metode analisis kelongsoran lereng dilakukan dengan metode kelongsoran manual.

4. Analisis yang dipakais yaitu dengan metode bishop.

\section{Tujuan Penelitian}

1. Mengetahui nilai $\phi$ dan $\mathrm{C}$ ambang batas yang sesuai dengan kondisi lapangan.

2. Mengetahui nilai Faktor Keamanan lereng pada lereng di jalan Ahmad Yani.

\section{Manfaat Penelitian}

Manfaat teoritis yang dapat diperoleh dari penelitian ini adalah hasil dari penelitian ini dapat menjadi salah satu konstribusi dalam bidang Ilmu Rekayasa Geoteknik yang berguna sebagai salah satu bahan pembelajaran bagi para pembaca dikemudian hari.

Manfaat praktis yang dapat diperoleh dari penelitian Tugas Akhir ini adalah mengetahui Faktor Keamanan (FK) pada kestabilan lereng di jalan Ahmad Yani berdasarkan hasil analisis nilai Faktor Keamanan lereng sehingga dapat dilakukan penanganan lereng yang dikategorikan dalam keadaan seimbang tetapi berpotensi longsor serta lereng dalam keadaan tidak aman (kritis). Tujuan dari penanganan ini adalah agar kegiatan di jalan raya dapat bejalan dengan baik.

\section{TINJAUAN PUSTAKA}

\section{Longsoran atau Gerakan Tanah}

Pengertian longsoran (landslide) dengan gerakan tanah (massmovement) mempunyai kesamaan. Untuk memberikan definisi longsoran perlu penjelasan keduanya. Gerakan tanah ialah perpindahan massa tanah/batuan pada arah tegak, mendatar atau miring dari kedudukan semula. Gerakan tanah mencakup gerak rayapan dan aliran maupun longsoran. Menurut definisi ini longsoran adalah bagian gerakan tanah (Purbohadiwidjojo, 1998). Jika menurut definisi ini perpindahan massa tanah/batu pada arah tegak adalah termasuk 
gerakan tanah, maka gerakan vertikal yang mengakibatkan bulging (lendutan) akibat keruntuhan fondasi dapat dimasukkan pula dalam jenis gerakan tanah. Dengan demikian pengertiannya menjadi sangat luas. Kelompok utama gerakan tanah (massmovement) terdiri atas rayapan (creep) dan longsoran (landslide) yang dibagi lagi menjadi sub-kelompok gelinciran (slide), aliran (flows), jatuhan (fall) dan luncuran (slip). Definisi longsoran (landslide) adalah luncuran atau gelinciran (sliding) atau jatuhan (falling) dari massa batuan/tanah atau campuran keduanya.

\section{Karakteristik dan Sifat-Sifat Tanah}

Tanah dalam ilmu mekanika tanah dimaksudkan untuk mencakup semua bahan dari tanah berukuran lempung sampai kerakal. Dalam ilmu mekanika tanah, tanah dibagi menjadi dua berdasarkan cara terbentuknya yaitu tanah residu dan tanah endapan. Tanah residu (residual soil) merupakan tanah yang terbentuk langsung akibat pelapukan kimiawi. Tanah residu tetap pada tempat pembentukannya yaitu di atas batuan asalnya. Hujan menyebabkan erosi dan tanah diangkut melalui sungai sampai mencapai laut atau danau. Di sini terjadi pengendapan lapisan demi lapisan pada dasar laut atau danau. Proses ini berlangsung selama ribuan atau jutaan tahun. Tanah ini disebut tanah endapan (sedimentary soil) atau tanah yang terangkut.

Perbedaan dari tanah residu dan tanah endapan yaitu pada tanah residu yang terbentuk langsung dari batu asalnya, pada umumnya ada hubungan erat antara sifat tanah dan jenis batuan asalnya. Pada tanah endapan tidak ada hubungan antara sifatnya dan batuan asalnya. Pada tanah residu terdapat struktur, yaitu butirnya teratur ataupun terikat satu sama lain sehingga membentuk kerangka tanah. Akibat adanya struktur ini, sifat tanah menjadi berbeda sifat seandainya tidak ada struktur, yaitu butirnya merupakan kumpulan butir lepas saja.

\section{Struktur Tanah}

Tanah tersusun dari butiran tanah atau partikel lainnya dan rongga-rongga atau pori di antara partikel butiran tanah. Rongga-rongga terisi sebagian atau seluruhnya dengan air atau zat cair lainnya. Rongga-rongga tanah yang tidak terisi oleh air atau zat cair akan terisi oleh udara atau bentuk lain dari gas. Volume yang ditempati oleh bagian besar tanah pada umumnya termasuk bahan penyusun lainnya yaitu bagian padat, cair dan gas/udara yang selanjutnya dikenal sebagai system tiga fase tanah (three phase systems).

Sifat-sifat mekanis penting tanah, seperti kekuatan (strength) dan pemampatan (compressibility), secara langsung berhubungan dengan atau paling tidak dipengaruhi oleh faktor-faktor seperti rapat massa (density), berat volume (unit weight), angka pori (void ratio) dan derajat kejenuhan (degree of saturation). Selain ketiga faktor tersebut terdapat satu faktor yang jarang diterangkan yaitu berat volume dibawah air (submerged unit weight). Definisi parameter ini adalah $\mathrm{\gamma}^{1}=\mathrm{\gamma}-\mathrm{\gamma}_{\mathrm{w}}$, dimana $\gamma^{1}$ adalah berat satuan tanah terendam (submerged). Jadi, berat satuan terendam adalah berat efektif pada tanah di bawah muka air tanah.Berat satuan ini memeperhitungkan tegangan mengapung yang berasal dari air.

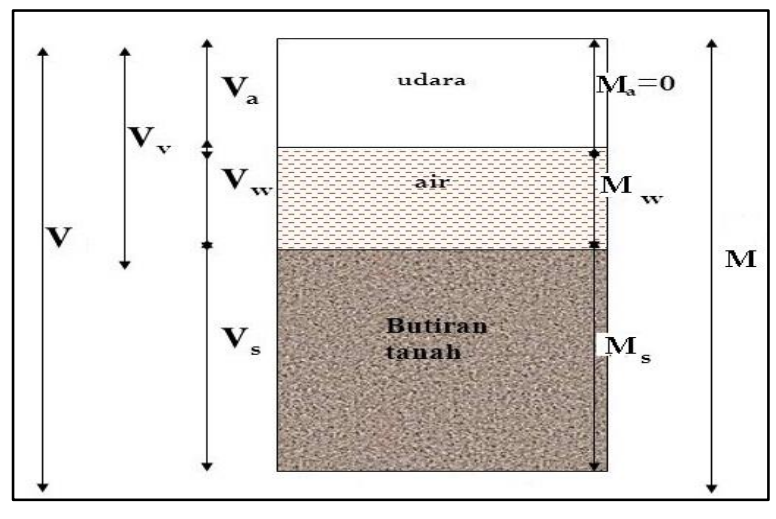

Gambar 1. Struktur tanah

Keterangan:

$\mathrm{Ma}=$ Massa udara $(=0)$

Mw = Massa air

Ms = Massa butiran tanah

$\mathrm{M} \quad=$ Massa total

$\mathrm{Va} \quad=$ Volume udara

$\mathrm{Vw}=$ Volume air

Vs $\quad=$ Volume butiran tanah

$\mathrm{Vv} \quad=$ Volume pori

$\mathrm{V} \quad=$ Volume total

\section{Sifat Fisik Tanah}

Sifat fisik tanah adalah sifat-sifat yang terkandung dalam tanah. Sifat fisik tanah dapat terlihat dan dapat diamati dengan mudah. Sifat fisik tanah antara lain adalah:

1. Tekstur tanah

Tekstur tanah disusun dari butir-butir tanah dengan berbagai ukuran. Butiran yang berukuran $>2 \mathrm{~mm}$ adalah butiran kasar dan <2mm adalah butiran halus.

2. Struktur tanah 
Struktur tanah adalah butir-butir penyusun tanah yang terikat satu sama lain dan membentuk gumpalan-gumpalan tanah.

3. Bobot isi tanah

Bobot isi tanah merupakan kerapatan tanah persatuan volume yang dinyatakan dalam dua batasan yaitu: kerapatan partikel (bobot partikel) dan kerapatan massa (bobot isi).

4. Konsistensi tanah

Konsistensi tanah menunjukkan integrase antar kekuatan daya kohesi butir-butir tanah dengan daya adhesi butir-butir tanah dengan benda lain. konsistensi tanah dapat dilihat dari: tingkat kelekatan, dan tingkat plastisitas.

5. Kadar air

Kadar air merupakan hal/komponen penting dalam tanah.Seperti kita ketahui, tanah adalah material yang sangat mudah menyerap tanah dan tanah juga sangat mudah merembeskan air, tergantung konsistensi tanah.

\section{Sifat Mekanik Tanah}

Sifat mekanis tanah adalah sifat-sifat tanah yang mengidentifikasikan kondisi tanah atau perilaku tanah akibat diberikannya gaya terhadap tanah. Sifat mekanis tanah tidak akan diketahui, tanpa pengujian laboratorium. Sifat mekanik tanah antara lain: kuat geser tanah, daya dukung tanah, permeabilitas tanah.

\section{Kestabilan Lereng}

Kestabilan lereng merupakan kemampuan tanah pada permukaan yang tidak horizontal yang mengakibatkan komponen gravitasi cenderung memberikan tekananan yang besar ke bawah, sehingga adanya perlawanan terhadap geseran yang dapat dikerahkan oleh tanah sehingga dapat mengakibatkan kelongsoran (Nermeen Albataineh, 2006). Gaya yang menyebabkan ketidak mantapan (gaya penggerak) dalam hal ini adalah berat tanah itu sendiri dan gaya penahan berasal dari kuat geser tanah, sedangkan gaya luar biasanya dapat dipengaruhi oleh adanya gempa atau aktivitas di atas dari lereng tersebut (berat kendaraan yang lewat atau bangunan yang ada di atas lereng). Pola keruntuhan yang akan terjadi tidak pasti dan tidak dapat ditentukan sebelum melakukan analisis. Untuk lereng dengan tanah seragam, keruntuhan umumnya terjadi pada bidang yang mendekati busur lingkaran.

Analisis kestabilan lereng dilakukan untuk mengevaluasi kondisi kestabilan kerja dari lereng galian, lereng timbunan maupun lereng alami. Tujuan akhir dari analisis kestabilan lereng adalah untuk mengetahui apakah lereng tersebut dalam keadaan stabil atau tidak stabil. Apabila dalam keadaan stabil maka keadaan stabil tadi harus tetap dipertahankan tetapi apabila lereng dalam keadaan tidak stabil maka harus segera dilakukan perbaikan pada lereng untuk mencegah kelongsoran.

\section{Teori Kestabilan Lereng}

Analisis kestabilan lereng pada umumnya didasarkan pada konsep keseimbangan plastis batas (limit plastic equilibrium) dalam (Albataineh, 2006). Maksud dari analisis kestabilan lereng adalah untuk menentukan faktor aman dari bidang longsor yang potensial. Dalam analisis kestabilan lereng, beberapa anggapan dibuat, yaitu:

1. Kelongsoran lereng terjadi di sepanjang permukaan bidang longsor tertentu dan dianggap sebagai masalah bidang dua dimensi.

2. Massa tanah yang longsor dianggap sebagai benda massif.

3. Tahanan geser dari massa tanah, di sembarang titik sepanjang bidang longsor tidak tergangtung dari orientasi permukaan longsor, atau dengan kata lain, kuat geser tanah dianggap isotropis.

4. Faktor aman di definisikan dengan memperhatkan tegangan geser rata-rata sepanjang bidang longsor potential dan kuat geser tanah rata-rata sepanjang permuakaan longsoran. Jadi, kuat geser tanah mungkin terlampaui di titik-titik tertentu pada bidang longsornya, padahal faktor aman hasil hitungan lebih besar dari 1 .

Faktor aman didefinisikan sebagai perbandingan nilai antara gaya yang menahan dan gaya yang menggerakan (Nermeen Albataineh, 2006), atau dengan persamaan:

$$
F=\frac{\mathrm{s}}{\mathrm{Sd}}
$$

keterangan:

$\mathrm{F}$ = Nilai Faktor Keamanan

$\mathrm{S}=$ Kekuatan geser tanah maksimum $\left(\mathrm{kN} / \mathrm{m}^{2}\right)$

$\mathrm{Sd}=$ Tegangan geser $\left(\mathrm{kN} / \mathrm{m}^{2}\right)$

\section{Metode Bishop}

Metode irisan yang menganggap bahwa gayagaya yang bekerja pada sisi-sisi irisan mempunyai resultan nol pada arah vertikal (A.W. Bishop, 1964). Persamaan kekuatan geser dalam tinjauan tegangan efektif yang dapat dikerahkan tanah, hingga tercapainya kondisi keseimbangan batas dengan memperhatikan Faktor Keamanan adalah sebagai berikut:

$$
\mathrm{S}=\frac{\mathrm{c}^{\prime}}{F}+(\sigma-\mathrm{u}) \frac{\tan \varphi^{\prime}}{F}
$$


keterangan:

$\mathrm{S}=$ Kekuatan geser tanah $\left(\mathrm{kN} / \mathrm{m}^{2}\right)$

$\mathrm{c}^{\prime}=$ Kohesi tanah $\left(\mathrm{kN} / \mathrm{m}^{2}\right)$

$\mathrm{F}=$ Nilai Faktor Keamanan

$\Sigma=$ Tegangan normal pada bidang longsor $\left(\mathrm{kN} / \mathrm{m}^{2}\right)$

$\mathrm{U}=$ Tekanan air pori $\left(\mathrm{kN} / \mathrm{m}^{2}\right)$

$\varphi^{\prime}=$ Sudut geser dalam efektif $\left(^{\circ}\right)$

Metode Bishop dilakukan dengan membuat sayatan pada sebuah bidang yang berbentuk busur lingkaran. Untuk pembuatan busur lingkaran yaitu dengan membuat pusat busur lingkaran berdasarkan grafik. Kemudian setiap sayatan akan dihitung satu-persatu. Jadi, dapat dikatakan bahwa nilai Faktor Keamanan dari setiap sayatan ini berbeda dan nilai Faktor Keamanan terkecil (terkritis) akan diambil sebagai nilai Faktor Keamanan dari lereng.

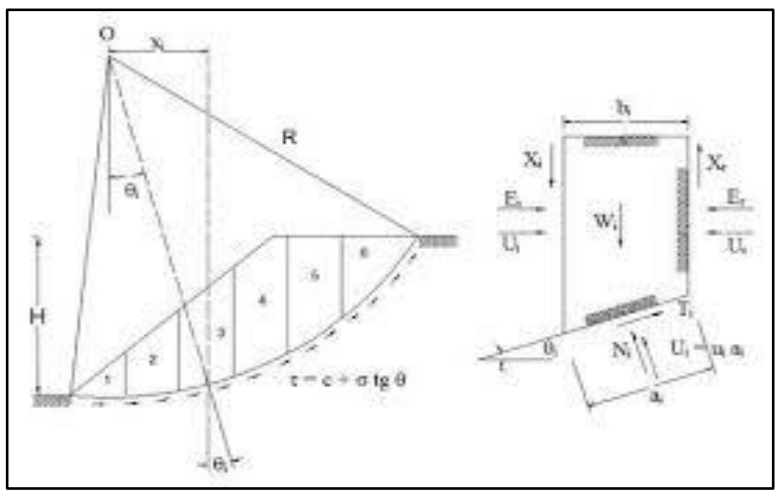

Gambar 2. Gaya-gaya yang bekerja pada irisan metode bishop

\section{Faktor Keamanan}

Faktor keamanan terhadap longsoran didefinisikan sebagai perbandingan kekuatan geser maksimum yang dimiliki tanah dibidang longsor yang diandaikan (s) dengan tahanan geser yang diperlukan untuk keseimbangan $(\tau)$,

$$
F k=\frac{s}{\tau}
$$

Tingkat nilai faktor keamanan.

Tabel 1. Tingkat nilai FK

\begin{tabular}{cc}
\hline Fk & Keterangan \\
\hline$>1,5$ & Stabil \\
$1,07<\mathrm{Fk}<1,5$ & Kritis \\
$<1,07$ & Labil \\
\hline
\end{tabular}

\section{METODE PENELITIAN}

\section{Lokasi Penelitian}

Lokasi penelitian berlokasi didaerah Puruk cahu Kabupaten Murung Raya, tepatnya pada Jln. Ahmad Yani. Dimana pada lokasi terjadi longsor, tepatnya pada jalan.

Untuk mencapai lokasi B, dari Palangka Raya dapat dijangkau dengan rute : Palangka Raya-Puruk Cahu / Lokasi longsor, jarak antara Palangka Raya ke Puruk Cahu kurang lebih 405 $\mathrm{km}$. Untuk mencapai lokasi dapat diakses dengan jalan darat menggunakan kendaraan roda dua maupun roda empat kurang lebih sembilan (9) jam perjalanan.

\section{Pengambilan Sampel Tanah}

Pengambilan sampel dilakukan secara langsung dilapangan dengan menggunakan bor geotek (bor mesin/drilling machine). Pengambilan sampel dengan bor mesin bertujuan memaksimalkan pengambilan sampel tanah hingga lapisan paling dalam, karena jika hanya memakai bor tangan/hand boring akan sangat sulit menjangkau lapisan tanah lebih dalam. Bor mesin mengunakan tenaga diesel sebagai penggerak bor. Alat ini mampu menjangkau lapisan tanah terdalam hingga \pm 100 meter dari permukaan tanah. Pengambilan sampel tanah dilakukan pada titik bor dan untuk bor akan diambil sampel tanah dengan interval 2 meter. Pengambilan sampel tanah dimaksud adalah untuk memenuhi sampel/material tanah yang akan diteliti/diuji dilaboratorium. Sampel yang dimaksud berupa sampel tanah asli dan tanah timbunan yang ada pada lokasi longsor. Lalu sampel akan diteliti lebih lanjut di laboratorium mekanika tanah.

Langkah kerja yang dilakukan adalah:

1. Menentukan titik pengambilan sampel.

Menentukan titik bertujuan memudahkan pekerjaan selanjutnya pada saat pengeboran. Karena penentuan titik pengambilan sampel akan memudahkan pengebor dilapangan akan dimana titik-titik bor dilaksanakan.

2. Menentukan kedalaman pengeboran untuk pengambilan sampel. Kedalaman lapisan yang akan kita jangkau mengacu kepada data yang dibutuhkan. Dan menghemat biaya yang keluar/serta estimasi waktu.

3. Pengambilan sampel/material yang akan diuji. Pengambilan sampel ini dilakukan dengan cara mengebor tanah, dengan mata bor yang berputar yang akan terus membuka tiap lapisan tanah dan sampel tanah yang diambil akan masuk kedalam tabung shelby yang gunanya membungkus serta mengamankan sampel tanah yang diambil. 


\section{Pengambilan Data Geometri Lereng}

Pengambilan data permukaan lereng dimaksud adalah untuk mengetahui bentuk dan permukaan lereng. Dari data yang didapat, bisa ditampilkan gambar permukaan lereng pada daerah longsor yang diteliti. Dimana data ini diperlukan untuk mencocokkan bentuk lereng dilapangan dengan model longsor setelah analisa.

\section{Pengolahan Data}

Pengolahan data dalam penelitian tugas akhir ini menggunakan Metode Kelongsoran Manual dan analisis stabilitas lereng yang digunakan adalah metode Bishop. Adapun tata laksana dari pengolahan data adalah sebagai berikut:

1. Mengumpulkan data yang terdiri dari geometri lereng, sudut geser tanah, kohesi tanah, bobot isi tanah, serta kondisi muka air tanah pada lereng.

2. Data geometri lereng digunakan untuk menggambarkan bentuk lereng menggunakan. Metode Kelongsoran Manual dengan cara memasukan nilai jarak datar dan ketinggian.

3. Setelah bentuk lereng selesai digambarkan maka masukan parameter muka air tanah. Apabila parameter muka air tanah tidak tersedia maka dapat diasumsikan bahwa muka air tanah mengikuti dari bentuk lereng. Pengasumsian ini dilakukan untuk mengantisipasi apabila lereng dalam keadaan jenuh air. Serta dapat diasumsikan pula kondisi lereng dalam keadaan tidak jenuh air sehingga terdapat dua model lereng yang berbeda.

4. Menggambarkan lapisan material lereng berdasarkan stratigrafi yang diperoleh dari hasil pemboran. Setelah selesai menggambarkan keadaan lapisan material lereng maka dilakukan input nilai parameter tanah.

5. Setelah semua parameter selesai dimasukan dan dirasa benar maka selanjutnya melakukan perhitungan nilai Faktor Keamanan menggunakan salah satu fungsi (Analysis, Compute) pada Metode Kelongsoran Manual.

6. Menampilkan hasil perhitungan nilai Faktor Keamanan dengan salah satu fungsi (Analysis, Interpret) pada Metode Kelongsoran Manual. Mengeksport gambar ke format JPEG dan menyimpan gambar sebagai hasil dari perhitungan Faktor Keamanan pada lereng penelitian.

\section{ANALISIS DAN PEMBAHASAN}

\section{Pengujian Sifat Mekanik Tanah Tanah}

Sifat mekanis tanah adalah sifat-sifat tanah yang mengidentifikasi kodisi tanah atau perilaku tanah akibat diberikannya gaya terhadap tanah.

Berdasarkan penelitian yang dilakukan terhadap tanah longsoran yang terdapat pada jalan Ahmad Yani Puruk Cahu Kabupaten Murung Raya. Di dapat hasil dari sifat-sifat mekanik tanah yaitu gaya geser tanah sebagai data parameter perhitungan Faktor keamanan pada longsoran.

Tabel 2. Rekapitulasi hasil grafik hubungan tegangan geser dan tegangan normal

\begin{tabular}{ccc}
\hline No. & Sudut Geser Dalam $($ ( $)\left(^{\circ}\right)$ & $\begin{array}{c}\text { Kohesi(C) } \\
(\mathrm{kN} / \mathrm{m} 3)\end{array}$ \\
\hline $\begin{array}{c}\text { BH- } \\
01\end{array}$ & 10 & 130 \\
$\begin{array}{c}\text { BH- } \\
02\end{array}$ & 16 & 90 \\
\hline
\end{tabular}

Sumber : Analisis Data 2019

\section{Hasil Analisis Data Dengan Metode Bishop}
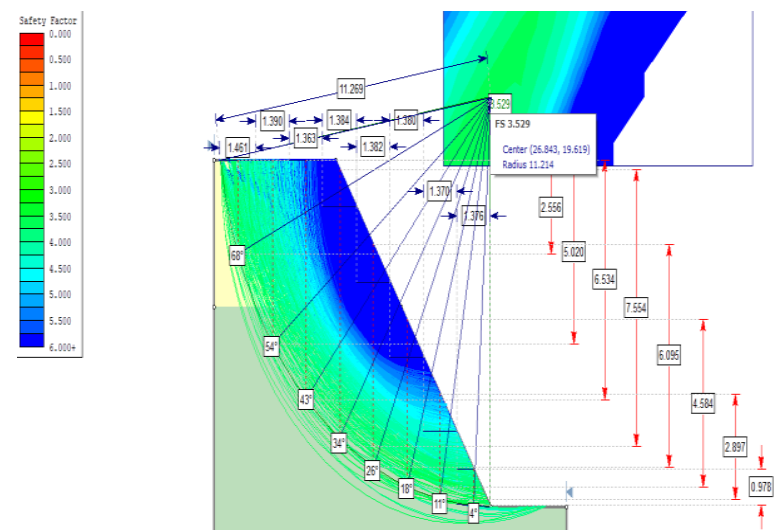

Gambar 3. Analisis data menggunakan metode bishop

\section{Rumus :}

$\mathrm{FS}=\frac{\left(c^{\prime} b n+W n \tan \varphi\right) \frac{1}{m \alpha}}{W n \sin \alpha}$
$\mathrm{M} \alpha=\cos \alpha\left(1+\frac{\tan \alpha \tan \varphi}{F}\right)$

Perhitungan faktor keamanan disajikan dalam bentuk tabel perhitungan faktor keamanan pada setiap irisan tebing. 


\section{Perhitungan Faktor Keamanan Tanpa Pengaruh Tekanan Air pori (U) atau Pada saat Kering}

Tabel 3. Perhitungan faktor keamanan menggunakan metode bishop

\begin{tabular}{ccccccccc}
\hline No.Irisan & $\mathbf{b}$ & $\mathbf{h 1}$ & $\mathbf{h 2}$ & $\boldsymbol{\alpha}$ & $\mathbf{W 1}$ & $\mathbf{W 2}$ & Wtotal & sin $\boldsymbol{\alpha}$ \\
& & & & & & & & \\
\hline & $\mathrm{m}$ & $\mathrm{m}$ & $\mathrm{m}$ & $\circ$ & $\gamma$ bh $1(\mathrm{kN})$ & $\gamma$ bh $(\mathrm{kN})$ & $\mathrm{W} 1+\mathrm{W} 2(\mathrm{kN})$ & $\circ$ \\
& & & & & & & & \\
\hline $\mathbf{1}$ & 1 & 2 & 3 & 4 & 5 & 6 & 7 & 8 \\
\hline $\mathbf{2}$ & 1,461 & 2,556 & 0,00 & 68,00 & 74,68632 & 0,00 & 74,69 & 0,927184 \\
\hline $\mathbf{3}$ & 1,363 & 5,020 & 0,00 & 54,00 & 139,556 & 0,00 & 139,56 & 0,809017 \\
\hline $\mathbf{4}$ & 1,384 & 7,554 & 0,00 & 43,00 & 178,1168 & 0,00 & 178,12 & 0,681998 \\
\hline $\mathbf{5}$ & 1,382 & 6,095 & 0,00 & 26,00 & 168,4658 & 0,00 & 168,47 & 0,438371 \\
\hline $\mathbf{6}$ & 1,380 & 4,584 & 0,00 & 18,00 & 126,5184 & 0,00 & 126,52 & 0,309017 \\
\hline $\mathbf{7}$ & 1,370 & 2,897 & 0,00 & 11,00 & 79,3778 & 0,00 & 79,38 & 0,190809 \\
\hline $\mathbf{8}$ & 1,376 & 0,978 & 0,00 & 4,00 & 26,91456 & 0,00 & 26,91 & 0,069756 \\
\hline
\end{tabular}

Tabel 3. Lanjutan

\begin{tabular}{ccccccccc}
\hline No.Irisan & $\mathbf{A}$ & $\mathbf{h W}$ & $\mathbf{U w}$ & $\mathbf{U . b}$ & $\begin{array}{c}\text { Wtot- } \\
\text { bu }\end{array}$ & $\begin{array}{c}\text { (wtot- } \\
\mathbf{U} \text {.b)tan } \mathbf{\Phi}\end{array}$ & $\mathbf{c}$ 'b & $\mathbf{B}(\mathbf{1 4 + 1 5})$ \\
& Wtot.sin $\alpha$ & $\mathrm{m}$ & $\mathrm{hw} \gamma \mathrm{w}$ & $\mathrm{kN}$ & $\mathrm{kN}$ & $\mathrm{KN}$ & $\mathrm{kN}$ & $\mathrm{kN}$ \\
& & & & & & & & \\
\hline & 9 & 10 & 11 & 12 & 13 & 14 & 15 & 16 \\
\hline $\mathbf{1}$ & 69,2480 & 0,00 & 0,00 & 0,00 & 74,69 & 13,17 & 126,67 & 139,84 \\
\hline $\mathbf{2}$ & 112,9032 & 0,00 & 0,00 & 0,00 & 139,56 & 24,60 & 120,51 & 145,12 \\
\hline $\mathbf{3}$ & 121,4754 & 0,00 & 0,00 & 0,00 & 178,12 & 31,40 & 118,17 & 149,57 \\
\hline $\mathbf{4}$ & 116,9243 & 0,00 & 0,00 & 0,00 & 209,09 & 36,86 & 119,99 & 156,86 \\
\hline $\mathbf{5}$ & 73,8505 & 0,00 & 0,00 & 0,00 & 168,47 & 29,70 & 119,82 & 149,52 \\
\hline $\mathbf{6}$ & 39,0963 & 0,00 & 0,00 & 0,00 & 126,52 & 22,31 & 82,80 & 105,11 \\
\hline $\mathbf{7}$ & 15,1460 & 0,00 & 0,00 & 0,00 & 79,38 & 13,99 & 82,20 & 96,19 \\
\hline $\mathbf{8}$ & 1,8775 & 0,00 & 0,00 & 0,00 & 26,91 & 4,75 & 82,56 & 87,31 \\
\hline & 550,5211 & & & & & & & \\
\hline
\end{tabular}

Tabel 3. Lanjutan

\begin{tabular}{|c|c|c|c|}
\hline No.Irisan & $\begin{array}{l}\text { M dan } \\
\text { SF trial }\end{array}$ & $\begin{array}{c}\text { Atas/ } \\
\text { Bawah }\end{array}$ & $\begin{array}{l}\text { Safety } \\
\text { Factor }\end{array}$ \\
\hline & 1.5 & $16 / 17$ & Final \\
\hline & 17 & 18 & \\
\hline 1 & 0,4836 & 289,1561 & \multirow{8}{*}{$\begin{array}{l}\text { FS } \\
=\frac{1303,51}{550,52} \\
F S=2,3\end{array}$} \\
\hline 2 & 0,6829 & 212,5007 & \\
\hline 3 & 0,8115 & 184,3181 & \\
\hline 4 & 0,8948 & 175,2975 & \\
\hline 5 & 0,9503 & 157,3397 & \\
\hline 6 & 1,0101 & 104,0542 & \\
\hline 7 & 1,0181 & 94,4841 & \\
\hline \multirow[t]{2}{*}{8} & 1,0109 & 86,3637 & \\
\hline & & 1303,5141 & \\
\hline
\end{tabular}

Berdasarkan tabel hasil perhitungan di dapat Faktor keamanan (safety factor) sebesar $\mathrm{FS}=2,3$. Faktor keamanan (FS) = 2,3 dapat disimpulkan tingkat kelongsoran yang jarang terjadi (relatif stabil) pada saat kondisi lereng tidak dipengaruhi oleh tekanan air pori atau pada saat kondisi kering menurut tabel faktor keamanan (Bowles, 1998) 


\section{Perhitungan Faktor Keamanan Pengaruh Tekanan Air Pori (U) pada Saat Kondisi Hujan}

Tabel 4. Perhitungan faktor keamanan menggunakan metode bishop

\begin{tabular}{|c|c|c|c|c|c|c|c|c|}
\hline No.Irisan & b & h1 & h2 & $\alpha$ & W1 & W2 & Wtotal & $\sin \alpha$ \\
\hline & $\mathrm{m}$ & $\mathrm{m}$ & $\mathrm{m}$ & $\circ$ & $\gamma \mathrm{bh}_{1}(\mathrm{kN})$ & $\gamma \mathrm{bh}_{2}(\mathrm{kN})$ & $\mathrm{W} 1+\mathrm{W} 2(\mathrm{kN})$ & $\circ$ \\
\hline & 1 & 2 & 3 & 4 & 5 & 6 & 7 & 8 \\
\hline 1 & 1.461 & 2.556 & 0.00 & 68.00 & 74.68632 & 0.00 & 74.69 & 0.92718 \\
\hline 2 & 1.390 & 5.020 & 0.00 & 54.00 & 139.556 & 0.00 & 139.56 & 0.80902 \\
\hline 3 & 1.363 & 6.534 & 0.00 & 43.00 & 178.1168 & 0.00 & 178.12 & 0.682 \\
\hline 4 & 1.384 & 7.554 & 0.00 & 34.00 & 209.0947 & 0.00 & 209.09 & 0.55919 \\
\hline 5 & 1.382 & 6.095 & 0.00 & 26.00 & 168.4658 & 0.00 & 168.47 & 0.43837 \\
\hline 6 & 1.380 & 4.584 & 0.00 & 18.00 & 126.5184 & 0.00 & 126.52 & 0.30902 \\
\hline 7 & 1.370 & 2.897 & 0.00 & 11.00 & 79.3778 & 0.00 & 79.38 & 0.19081 \\
\hline 8 & 1.376 & 0.978 & 0.00 & 4.00 & 26.91456 & 0.00 & 26.91 & 0.06976 \\
\hline \multicolumn{9}{|c|}{ Tabel 4. Lanjutan } \\
\hline \multirow[t]{3}{*}{$\begin{array}{l}\text { No. } \\
\text { Irisan }\end{array}$} & $\mathbf{A}$ & hW & Uw & U.b & Wtot-bu & (wtot-U.b)ta & $\mathbf{c}^{\prime} \mathbf{b}$ & $B(14+15)$ \\
\hline & Wtot.sin $\alpha$ & $\mathrm{m}$ & hw $\gamma \mathrm{w}$ & $\mathrm{kN}$ & $\mathrm{kN}$ & $\mathrm{KN}$ & $\mathrm{kN}$ & $\mathrm{kN}$ \\
\hline & 9 & 10 & 11 & 12 & 13 & 14 & 15 & 16 \\
\hline 1 & 69,2480 & 0,00 & 0,00 & 0,00 & 74,69 & 13,17 & 126,67 & 139,84 \\
\hline 2 & 112,9032 & 0,00 & 0,00 & 0,00 & 139,56 & 24,60 & 120,51 & 145,12 \\
\hline 3 & 121,4754 & 0,00 & 0,00 & 0,00 & 178,12 & 31,40 & 118,17 & 149,57 \\
\hline 4 & 116,9243 & 0,00 & 0,00 & 0,00 & 209,09 & 36,86 & 119,99 & 156,86 \\
\hline 5 & 73,8505 & 0,00 & 0,00 & 0,00 & 168,47 & 29,70 & 119,82 & 149,52 \\
\hline 6 & 39,0963 & 0,00 & 0,00 & 0,00 & 126,52 & 22,31 & 82,80 & 105,11 \\
\hline 7 & 15,1460 & 0,00 & 0,00 & 0,00 & 79,38 & 13,99 & 82,20 & 96,19 \\
\hline \multirow[t]{2}{*}{8} & 1,8775 & 0,00 & 0,00 & 0,00 & 26,91 & 4,75 & 82,56 & 87,31 \\
\hline & 550,5211 & & & & & & & \\
\hline
\end{tabular}

Tabel 4. Lanjutan

\begin{tabular}{|c|c|c|c|}
\hline $\begin{array}{c}\text { No.Iris } \\
\text { an }\end{array}$ & $\begin{array}{c}\text { SF } \\
\text { trial }\end{array}$ & $\begin{array}{c}\text { Atas/Baw } \\
\text { ah }\end{array}$ & $\begin{array}{l}\text { Safety } \\
\text { Factor }\end{array}$ \\
\hline & 1.5 & $16 / 17$ & Final \\
\hline & 17 & 18 & \\
\hline 1 & 1.5 & 62.8291 & \multirow{8}{*}{$\begin{array}{l}\text { FS } \\
=\frac{503,167}{550,521} \\
F S=0,91\end{array}$} \\
\hline 2 & 1.5 & 63.8012 & \\
\hline 3 & 1.5 & 64.9873 & \\
\hline 4 & 1.5 & 67.6478 & \\
\hline 5 & 1.5 & 65.1802 & \\
\hline 6 & 1.5 & 62.6351 & \\
\hline 7 & 1.5 & 59.4648 & \\
\hline 8 & 1.5 & 56.6217 & \\
\hline & & 503.1671 & \\
\hline
\end{tabular}

Berdasarkan Berdasarkan tabel hasil perhitungan di dapat Faktor keamanan (safety factor) sebesar FS=0,91 ( Lereng Labil). Faktor keamanan $(\mathrm{FS})=0,91$ dapat disimpulkan tingkat kelongsoran pada lereng lebih rentan terjadi pada saat hujan karena curah hujan yang tinggi dapat mempengaruhi nilai phi $(\varphi)$ dan kohesi (C) menurun yang mengakibatkan terjadinya longsor.

\section{PENUTUP}

\section{Kesimpulan}

Berdasarkan hasil penelitian di lapangan, dan dari data yang didapat dari pengujian laboratorium, dan setelah analisis maka kesimpulan yang 
dapat diambil dari penelitian ini adalah sebagai berikut :

1. Dari hasil pengujian laboratorium nilai $\emptyset$ dan $\mathrm{C}$ di lokasi longsoran didapat dari pengujian kuat geser langsung (direct shear), maka didapat pada lapisan pertama nilai $\varnothing=10^{\circ}$ dan $\mathrm{C}=130 \mathrm{kN} / \mathrm{m}^{3}$.Pada lapisan kedua didapat nilai $\emptyset=16^{\circ}$ dan $\mathrm{C}=90 \mathrm{kN} / \mathrm{m}^{3}$.

2. Berdasarkan hasil pengujian laboratorium dan hasil analisis longsoran didapat nilai faktor keamanan (safety factor) pada longsoran di jalan Ahmad Yani,Kabupaten Murung Raya adalah $\mathrm{FK}=2,3$ tingkat kelongsoran jarang terjadi (relatif stabil) pada saat kondisi lereng tidak dipengaruhi oleh tekanan air pori atau pada saat kondisi kering dan $\mathrm{FK}=0,91$ dapat disimpulkan tingkat kelongsoran pada lereng lebih rentan terjadi pada saat hujan karena curah hujan yang tinggi dapat mempengaruhi nilai phi $(\varphi)$ dan kohesi (C) menurun yang mengakibatkan terjadinya longsor.

\section{Saran}

Berdasarkan hasil penelitian tugas akhir ini maka saran yang dapat diberikan adalah sebagai berikut:

1. Nilai faktor keamanan dilapangan hasil analisis perhitungan adalah 2,3. Nilai ini dapat dikatakan relatif stabil dan pada saat kondisi hujan $\mathrm{FK}=0,91$ tingkat kelongsoran lebih rentan terjadi karena mengakibatkan nilai phi $(\varphi)$ dan Kohesi (c) menurun. Sebaiknya perlu dilakukan penanganan yang lebih baik lagi dan meningkatkan dengan melakukan peningkatan dinding penahan tanah, mengingat dinding penahan tanah sebelumnya tidak mampu menahan longsor.

Ada baiknya dilakukan dengan melakukan kombinasi geotekstil dan dinding penahan tanah.

2. Terjadinya longsoran pada bahu jalan akibat menurunnya nilai $\operatorname{phi}(\varphi)$ dan kohesi(C) pada tanah akibat air,terutama akibat hujan. Kondisi air hujan yang tidak segera dialirkan atau lambatnya air meresap kedalam tanah sehingga mengakibatkan kantong-kantong air dalam tanah.Untuk itu perlu adanya peningkatan drainase yang baik untuk pengaliran air.

\section{DAFTAR PUSTAKA}

Albaitaneh, Narmeen., (2006).Perbandingan Nilai antara Gaya Menahan dan Gaya yang Menggerakkan.

Bishop, A.W., (1955). The Use of Slip Surface in The Stability of Analysis Slopes, Geotechnique, Vol 5. London

Bowles, J. (1984). Sifat-Sifat Fisis dan Geoteknis Tanah (Mekanika Tanah). Edisi Bowles, Joseph E., Hainim Johan K., 1991. Sifat-Sifat Fisis dan Geoteknis Tanah (Mekanika Tanah), Edisi Kedua, Penerbit Erlangga, Jakarta.

Hardiyatmo, Hari Christady. 1992. Mekanika Tanah 1. Jakarta : Gramedia Pustaka Utama.

Hardiyatmo, Hari Christady. (1994). Mekanika Tanah 2. Jakarta : Gramedia Pustaka Utama.

Hirnawan, R.F., (1993), Ketanggapan Stabilitas Lereng Perbukitan Rawan Gerakan tanah atas Tanaman Keras, Hujan \& Gempa, Disertasi, UNPAD, 302pp.

M.Das, Braja. (1985). Mekanika Tanah (Jilid 1). Surabaya: Erlangga.

M.Das, Braja. 1994. Mekanika Tanah (Jilid 2). Surabaya: Erlangga

Sutarman E., (2013). Konsep dan Aplikasi Pengantar Teknik Sipil.ANDI. Bandung

Tjokorda Gde Suwarsa Putra, Made Dodiek Wirya Ardana dan Made Aryati. 2010. Analisis Stabilitas Lereng Pada Badan Jalan Dan Perencanaan Perkuatan Dinding Penahan Tanah (Studi Kasus Jalan Raya Selemadeg, Desa Bantas, Kecamatan Selemadeg Timur, Kabupaten Tabanan).

Turangan, Octovian Cherianto Parluhutan Rajagukguk. (2014). Analisis Kestabilan Lereng Dengan Metode Bishop. 